ENTITA : Jurnal Pendidikan IImu Pengetahuan Sosial dan IImu-IImu Sosial http://ejournal.stainpamekasan.ac.id/index.php/entita P-ISSN:2715-7555 E-ISSN:2716-1226

\title{
Strategi Pembangunan Pariwisata Daerah Berkelanjutan Melalui Konsep Ekowisata Berbasis Kearifan Lokal
}

\author{
Abd Hannan \\ Fithriyah Rahmawati \\ Fakultas Tarbiyah, Institut Agama Islam Negeri (IAIN) Madura. \\ Hannan.taufiqi@gmail.com, fithriyahrahmawati90@gmail.com.
}

\begin{abstract}
This study is entitled, The Strategy of Sustainable Tourism Development in Region through the Ecotourism Concept Based on Local Wisdom. There are three main issues that will be discussed in this study, namely the concept of ecotourism, sustainable development, and the concept of local wisdom, These three issues will be elaborated through two research questions, what is meant by the concepts of sustainable tourism, ecotourism, and local wisdom? How to build sustainable Pamekasan tourism through the concept of ecotourism based on local wisdom? This study is a qualitative study with a literature approach. The theory used in this research is the theory of regional development from Richard Florida. Theoretically, this study has a major contribution in terms of enriching social scientific treasures, especially those that deal with development issues. Whereas in practice, this study has a major contribution in offering solutive ideas, especially with regard to the development of tourism in the Pamekasan area. In general, the findings of this study include descriptive explanations regarding natural-social diversity in Pamekasan, and in-depth analysis of the role and strategic functions of Pamekasan's local wisdom in realizing sustainable regional ecotourism development.
\end{abstract}

Keywords: Ecotourism, Local Wisdom, Sustainable Development

\begin{abstract}
Abstrak
Studi ini berjudul, Strategi Pembangunan Pariwisata Daerah Berkelanjutan melalui Konsep Ekowisata Berbasis Kearifan Lokal. Terdapat tiga isu utama yang akan dibahas dalam kajian ini; konsep ekowisata, pembangunan berkelanjutan, dan konsep kearifan lokal. Ketiga isu tersebut akan dijabarkan melalui dua pertanyaan penelitian, apa yang dimaksud dengan konsep pariwisata berkelanjutan, ekowisata, dan kearifan lokal? Bagaimana membangun pariwisata daerah berkelanjutan melalui konsep ekowisata berbasis kearifan lokal? Studi ini merupakan studi kualitatif dengan pendekatan kepustakaan. Teori yang digunakan dalam penelitian ini adalah teori pembangunan kawasan daerah dari Richard Florida. Secara teoritis, studi ini memiliki sumbangsih besar dalam hal memperkaya khazanah keilmuan sosial, khususnya yang bersentuhan dengan isu-isu pembangunan. Sedangkan secara praktik, studi ini memiliki sumbangsih besar dalam menawarkan gagasan solutif, khusunya berkenaan dengan pembangunan pariwisata daerah Pamekasan. Secara umum, temuan besar studi ini memuat penjelasan deskriptif perihal keanekaragaman alam-sosial di Pamekasan, serta analisa mendalam tentang peran dan fungsi strategis kearifan lokal Pamekasan dalam mewujudkan pembangunan ekowisata daerah yang berkelanjutan.
\end{abstract}

Kata Kunci: Ekowisata, Pembangunan Berkelanjutan, Nilai Kearifan Lokal Received : 29 Maret 2020; Revised: 13 Meil 2020; Accepted: 29 Mei 2020 


\section{Pendahuluan}

Isu pembangunan merupakan salah satu isu sosial yang sejauh ini mengundang perhatian banyak kalangan, baik pada tataran teoritik maupun praktik. Pada tataran teoritis, wacana seputar pembangunan menemukan momentumnya ketika arah pembangunan dunia dihadapkan pada 'kiblat' baru, yakni pembangunan berkelanjutan. Sedangkan pada tataran praktik, isu pembangunan menjadi semakin nyaring dibicarakan seiring munculnya persoalan pembangunan yang selama ini mengancam stabilitas dan keberlangsungan hidup masyarakat global seperti kemiskinan, ketimpangan sosial, hingga pada isu paling krusial seperti pencemaran lingkungan (Sulistyo at al, 2010: 24). Berbagai gagasan pembangunan bermunculan, tujuannya tidak lain untuk memecahkan persoalan di atas, salah satunya adalah gagasan pembangunan berkelanjutan. Dalam kaitan, ini pembangunan berkelanjutan diharapkan dapat menjadi solusi, tidak saja dalam mereduksi kemiskinan dan ketimpangan sosial, namun juga dalam hal pemberdayaan dan pemanfaatan alam-sosial yang proporsional dan berkelanjutan.

Di Indonesia, respon dan perhatian pemerintah terhadap agenda pembangunan berkelanjutan tergambar jelas dalam peraturan presiden No 59 tahun 2017 tentang Pelaksanaan Pencapaian Tujuan Pembangunan Berkelanjutan, tanggal 4 Juli 2017 (Nur Hayati \& Alfana, 2016: 131). Melalui perpres tersebut, pemerintah berkeinginan besar melakukan penyesuaian rancangan pembangunan berkelanjutan dengan rencana pembangunan jangka panjang nasional tahun 2005-2025, dan rencana pembangunan jangka menengah nasional tahun 2015-2019. Penyelarasan tersebut kemudian diterjemahkan ke dalam rancangan kebijakan yang lebih terfokus lagi, berupa Aksi Rencana Nasional (ARN) dan Aksi Rencana Daerah (ARD).

Untuk mencapai sasaran pembangunan di atas, Indonesia menerapkan pola pembangunan dengan prinsip No One Will Be Left Behind, bahwa pelaksanaan pembangunan harus memberi manfaat untuk semua (Penuluh \& Fitri, 2016: 45). Pembangunan tidak boleh terpusat 
pada satu daerah atau satu kawasan, namun harus menyebar luas dan menyasar setiap daerah. Baik dari tingkat provinsi, kota, kabupaten, kecamatan, sampai struktur yang terkecil sekalipun, yaitu pedesaan. Untuk mewujudkan ini semua, perlu adanya transparansi proses sinkronisasi pembangunan. Bahwa pembangunan tidak boleh bersandar pada peran dan fungsi tunggal pemerintah, namun juga harus melibatkan semua pihak secara kolektif. Seperti halnya ormas, filantropi, pelaku usaha, akademisi, dan pemangku kepentingan lainnya. Baik dalam hal perencanaan, pelaksanaan, dan pemantauan serta evaluasi pembangunan ke depan, sehingga prinsip pemerataan SDGs benar-benar dapat terwujud.

Namun demikian, upaya pemerintah melakukan pemerataan pembangunan bukan tanpa kendala. Kenyataan Indonesia sebagai negara seribu pulau menimbulkan satu permasalahan tersendiri, terutama menyangkut bagaimana memastikan setiap daerah betul-betul tersentuh oleh pembangunan, terlepas dari aneka ragam keterbatasan dan problem sumberdaya yang dialami. Untuk menyiasati permasalahan ini, maka gagasan pembangunan berkelanjutan kemudian dimodifikasi melalui instrumen pembangunan berlandaskan nilai lokalitas, yang saat ini kita kenal dengan pembangunan berkearifan lokal (Hannan, 2017: 23). Pada perkembangan selanjutnya, konsep kearifan lokal mengalami peluasan makna, hingga akhirnya meluas ke ranah industri pariwisata, atau yang belakangan kita kenal dengan ekowisata daerah.

Bagi Indonesia, instrumen pembangunan kearifan lokal memuat nilai strategis, terutama untuk mengimbangi wilayah tertentu yang memiliki tipologi sosial khusus, seperti halnya kepulauan Madura. Dalam kaitan ini, tipologi sosial masyarakat Madura yang masih kental dengan sistem tradisional yang bertumpu simbol agama dan tradisi lokal, pada batasanbatasan tertentu dapat menjadi nilai strategis untuk dijadikan instrumen pengembangan dan pembangunan daerah setempat. Misal, menggagas pembangunan ekonomi daerah melalui konsep ekowisata berkelanjutan 
yang melandaskan pada nilai-nilai kearifan lokal setempat (Hannan, 2017: 25).

Untuk beberapa daerah seperti Madura, gagasan penguatan ekonomi berkelanjutan melalui ekowisata berkearifan lokal adalah pertimbangan cukup logis, bahkan sangat bernilai strategis. Hal ini didasarkan pada besarnya potensi alam sosial Madura yang memiliki beragam kekayaan kearifan lokal, baik yang berupa sosial budaya, sosial agama, dan eksotisme alam yang tersimpan indah di dalamnya (Dzulkarnain, 2016: 12). Dalam kaitan ini, beberapa daerah potensial Madura, sebut saja Kabupaten Sumenep yang selama ini identik dengan kepulauannya yang indah, seperti Pulau Gili Labak, Pulau Gili Yang, Pantai Sembilan, kesemuanya dapat dimaksimalkan sebagai instrumen pembangunan daerah setempat. Satu rupa dengan dengan Sumenep, yaitu Kabupaten Pamekasan. sekian banyak kekayaan alam sosial dan alam lingkungan di Pamekasan seperti halnya wisata api alam, kerapan sapi, pantai Jumiang, wisata religi berupa pesantren dan pasarean batu ampar, kesemunya merupakan area potensial yang dapat dimanfaatkan untuk mendongkrak pembangunan daerah.

Berangkat atas dasar pemikiran di atas, maka studi ini hendak mengkaji tentang penguatan konsep pembangunan berkelanjutan di Kabupaten Pamekasan, khususnya melalui gagasan ekowisata daerah berbasis kearifan lokal. Dengan demikian, beberapa isu krusial tentang pembangunan yang bersentuhan dengan konsep ekowisata, konsep pembangunan berkelanjutan, dan nilai kearifan lokal di Kabupaten Pamekasan, kesemuanya akan menjadi fokus pembahasan yang akan banyak dibahas dan dikaji dalam penelitian ini.

\section{Hasil dan Pembahasan}

\section{Ekowisata dan Kearifan Lokal; sebuah Tinjauan Konseptual}

a) Konsep Ekowisata

Konsep ekowisata sejatinya bukan hal baru dalam dunia pembangunan, konsep ini relatif sudah lama diperkenalkan, terutama semenjak munculnya berbagai permasalahan di sektor industri pariwisata, 
seperti kerusakan lingkungan, perilaku wisatawan yang mengancam ekosistem dan keberlangsungan eksistensi alam-sosial. Dalam artian, secara genealogis gagasan tentang ekowisata muncul sebagai respon banyak pihak atas berbagai kerusakan alam-sosial yang muncul akibat aktivitas industri pariwisata yang tidak mengindahkan ekosistem alam. Secara ketatabahasaan, ekowisata merupakan terjemahan dari kata ecotourism (ekoturisme). Nasikun dalam Fandelli (2000) menggunakan istilah ekowisata untuk menggambarkan bentuk kegiatan pariwisata baru yang muncul pada dekade 80an. Pada gilirannya konsep ekowisata mengalami perkembangan seiring berkembangnya industri pariwisata itu sendiri (Fandelli, 2000: 35).

Menurut Fennell (dalam Tanaya dan Rudiarto, 2014), ekowisata konsep era kekinian yang muncul sebagai bentuk berkelanjutan dari wisata berbasis sumberdaya alam. Prinsip utama kegiatan ekowisata adalah terletak pada pengalaman dan pembelajaran mengenai alam, yang dikelola dengan meminimalisir dampak, non-konsumtif, dan terpenting dari semuanya adalah orientasi diri yang mengedepankan nilai-nilai lokalitas (Tanaya \& Rudiarto, 2014: 71). Melengkapi pembacaan Fannel di atas, Goeldner (dalam Butcher, 2007) mendefinisikan ekowisata sebagai bentuk perjalanan menuju kawasan yang masih alami, itu bertujuan untuk memahami budaya dan sejarah alami dari lingkungannya, menjaga integritas ekosistem, sambil menciptakan kesempatan ekonomi untuk membuat sumber daya konservasi dan alam tersebut menguntungkan bagi masyarakat lokal (Butcher, 2007: 23).

Jika merujuk pada dua definisi di atas, terdapat beberapa kata kunci yang menjadi perhatian dan titik tekan ekowisata, yaitu pembelajaran atau edukasi, tidak berorientasi pada aspek tunggal profit, mengutamakan nilai lokal, dan terakhir adalah pemberdayaan masyarakat setempat, baik secara kualitas maupun kuantitas. Jika merujuk pada prinsip ini, jelas terlihat konsep ekowisata memiliki model berbeda dengan aktivitas pariwisata pada umumnya. Jika kebanyakan industri pariwisata konvensional lebih mengedepankan aspek eksploitasi dan ekonomi, 
bahkan tidak jarang bias praktik kapitalisasi ekonomi dan lingkungan, ekowisata lebih menekankan penyeimbangan diri antara ekonomi, perawatan lingkungan, dan penguatan eksistensi dan partisipasi masyarakat setempat. Melalui pendekatan demikian, kegiatan ekowisata memainkan peran diri bukan sebatas pada penggerak ekonomi daerah, namun lebih dari itu turut memainkan peran sebagai aktivis lingkungan yang aktif menjaga dan merawat alam-sosial secara menyeluruh.

Menurut Dowling (dalam Hill \& Gale, 2009), ciri penerapan konsep ekowisata dapat dilihat dari lima variabel. Lima (5) variabel di sini boleh dibilang merupakan konsep inti yang menjadi dasar pelaksanaan ekowisata. Kelima variabel yang dimaksud adalah bersifat alami, bahwa pariwisata dibangun berdasarkan sumber alamiah dan aspek natural, sisi orisinalitas dan keaslian panorama alam-lingkungan; Bersifat berkelanjutan secara ekologis, ekowisata menitikberatkan pada keberlanjutan ekologi alam; Lingkungannya bersifat edukatif, memberikan pembelajaran dan pengetahuan tentang arti pentinganya menjaga lingkungan alam-sosial sehingga mereka yang bergerak dalam industri wisata, baik sebagai pengelola ataupun penikmat, semunya memiliki kesadaran untuk menjaga dan melestarikan alam-sosial secara bersama dan bertanggung jawab; Menguntungkan masyarakat lokal, yaitu berorientasi pada penguatan daya tawar ekonomi, dan secara umum meningkatkan taraf kesejahteraan hidup masyarakat setempat (Hill \& Gale, 2009: 31).

b) Kearifan Lokal

Secara etimologi term 'nilai kearifan lokal' merupakan wujud kesatuan dari tiga kata dasar; nilai, kearifan, dan lokal. Menurut kamus besar bahasa Indonesia, nilai identik dengan sifat-sifat atau hal-hal yang penting, bermanfaat, dan berguna bagi kemanusiaan (Departemen Pendidikan dan Kebudayaan, 1999: 35). Adapun kata 'kearifan' berasal dari kata dasar arif, yang artinya bijaksana; cerdik pandai berilmu (Departemen Pendidikan dan Kebudayaan, 1999: 48). Lokal dalam pengertian Kamus Bahasa Indonesia berarti setempat; terjadi (berlaku, 
ada, dsb) di satu tempat saja, tidak merata (Departemen Pendidikan dan Kebudayaan, 1999: 530). Dengan demikian, nilai kearifan lokal adalah seperangkat nilai, kreativitas, atau pandangan yang memuat unsur kebijaksanaan, berkeadaban dan berperadaban yang berlangsung, berada, atau berlaku di satu tempat atau lokasi tertentu.

Adapun dalam pengertian terminologi, nilai kearifan lokal mengacu pada berbagai kekayaan alam-sosial yang tumbuh dan berkembang dalam sebuah masyarakat yang dikenal, dipercayai dan diakui sebagai elemen-elemen penting yang mampu mempertebal kohesi sosial di antara warga masyarakat. Pengertian ini mengisyaratkan bahwa nilai kearifan lokal hakikatnya muncul dan tumbuh dari kemampuan dan kreativitas masyarakat, yang kemudian terinternalisasi dalam kesadaran, pikiran, sikap, dan perilaku keseharian mereka. Konsep kohesi sosial dalam pembacaan ini mensyaratkan pada fungsi dan peran strategis kearifan lokal sebagai pembentuk integritas dan kesatuan masyarakat.

Menurut Mitchell, et al. (2000) dikutip oleh Aulia dan Arya Hadi Dharmawan (2013), term kearifan lokal berasal dari sistem pengetahuan dan pemberdayaan nilai-nilai lokal, tradisi, dan adat (Dharmawan, 2013: 346). Adapun menurut Zakaria (1994) sebagaimana dikutip Arafah (2002), konsep kearifan lokal bisa dipahami sebagai pengetahuan kebudayaan yang ada dalam sistem dan struktur sosial masyarakat tertentu yang di dalamnya memuat serangkaian pengetahuan kebudayaan yang terdiri dari sejumlah pengetahuan kebudayaan, serta tata cara pengelolaan, pemberdayaan, dan pemanfaatan sumber daya alam-sosial secara lestari (Arafah, 2002: 56). Kearifan tersebut berisikan gambaran tentang anggapan masyarakat yang bersangkutan tentang hal-hal yang berkaitan dengan struktur lingkungan, fungsi lingkungan, reaksi alam terhadap tindakan-tindakan manusia, dan hubungan-hubungan yang sebaiknya tercipta antara manusia (masyarakat) dan lingkungan alamnya (Dharmawan, 2013: 346).

Berkaitan dengan fungsi nilai kearifan lokal di atas, Sirtha (2003) sebagaimana dikutip oleh Sartini (2004), menyebutkan bahwa kearifan 
lokal yang terdiri dari kebudayaan, tradisi, pengetahuan, kreasi, dan seperangkat nilai-nilai lokal lainnya memiliki fungsi sebagai; 1) Konservasi dan pelestarian sumberdaya alam. 2) Mengembangkan sumber daya manusia. 3) Pengembangan kebudayaan dan ilmu pengetahuan. 4) Petuah, kepercayaan, sastra dan pantangan (Sartini, 2004: 127). Dalam kaitan inilah, maka fungsi-fungsi kearifan lokal di atas, khususnya fungsi pengembangan kebudayaan dan sumber daya alam, sesunguhnya dapat dimanfaatkan sebagai instrumen pembangunan. Kearifan lokal dapat menjadi jawaban dari sekian strategi pembangunan yang selama ini belum menunjukkan perkembangan, perubahan, dan kemajuan maksimal. Khususnya pembangunan di level daerah yang keberadaannya masih memegang teguh nilai dan norma lokalitas. Seperti halnya keseluruhan daerah yang ada di Kepulauan Madura.

\section{Deskripsi Nilai Kearifan Lokal Kabupaten Pamekasan}

Jika merujuk pada penjelasan Hubb De Jong (1989), Madura sebagai daerah kepulauan dapat dibagi menjadi dua kutub besar, yakni Madura Barat dan Madura Timur (De Jonge, 1989: 615). Madura Barat adalah daerah yang berada di sisi barat, dua daerah seperti Bangkalan dan Sampang adalah wilayah administratif yang masuk pada kutub ini. Sedangkan dua wilayah administratif lainnya, Pamekasan dan Sumenep masuk dalam Madura kutub timur. Namun demikian, meski secara geografis Hub De Jong membagi Madura dalam dua kutub antara barat dan timur, tidak lantas mencerminkan adanya perbedaan menyangkut bangunan sistem dan struktur sosial mereka. Dalam beberapa hal, antara Madura Barat dan Madura Timur memang memuat perbedaan, namun tidak dalam keseluruhan. Secara umum, baik Madura Barat maupun Madura Timur memiliki konstruksi sosial yang nyaris sama, bahkan sangat berdekatan.

Pun demikian dengan Kabupaten Pamekasan, sebagai salah satu daerah yang berada di bagian timur Madura, Pamekasan memiliki bangunan sistem sosial kebudayaan yang hampir sama dengan daerah Madura secara umum. Sekurang-kurangnya, kesamaan keduanya ada 
pada dua aspek, yakni bangunan struktur sosial setempat yang samasama mengandung nilai hierarki, kemudian kultur masyarakat yang kental dengan religiusitas (Hannan, 2019: 24). Namun di balik kesamaan tersebut, Pamekasan juga memiliki beberapa nilai lokalitas yang tercatat sebagai produk kebudayaan murni daerah Pamekasan sendiri. Baik dalam hal seni, budaya, dan makanan khas. Penjelasan lengkap tentang konstruksi sosial-budaya, sosial-agama, dan deskripsi alam-lingkungan di Pamekasan akan dijelaskan pada sub bab berikut.

a) Sosial Budaya

Dalam kajian sosial atau kemasyarakatan, budaya kita pahami sebagai kebiasaan yang dilakukan secara berulang-ulang dan di dalamnya terdapat nilai dan norma yang bersifat kolektif. Makna kebiasaan dalam budaya dapat berupa sikap, perilaku, ataupun pikiran. Selain itu, budaya turut juga dimaknai sebagai hasil karya, rasa, cipta yang didasarkan pada karsa (Sanderson, 2011: 56). Pengertian budaya dalam redaksi ini merupakan pengertian umum yang seringkali kali dikutip dalam ilmu sosial, khususnya antropologi dan sosiologi. Jika dikaitkan dengan kajian, maka term budaya merujuk pada keseluruhan cipta, rasa, dan karya yang di dalamnya memuat nilai dan norma kolektivitas masyarakat Pamekasan secara menyeluruh.

Memang relatif sulit mengetahui bentuk konkrit sistem dan struktur sosial masyarakat Pamekasan yang dapat menjadi pembeda dengan daerah Madura lainnya. Karena secara umum, semua daerah Madura, termasuk Pamekasan di dalamnya, memiliki bangunan sistem sosial yang sama-sama sarat nilai hierarki. Secara genealogis, sistem hierarki dalam kultur masyarakat Pamekasan tercermin jelas dalam pribahasa lokal setempat, yakni buppa', babhu', ghuruh, ratoh (bapak, ibu, guru, dan pemerintah). Secara indeksikalitas, bagian masyarakat Pamekasan pribahasa tersebut mengandung dua arti, yaitu sebagai representasi kuatnya cengkraman tradisi hierarki, selain itu pun juga merupakan pribahasa lokal yang menggambarkan standar kepatuhan masyarakat Pamekasan (Hannan, 2017: 7). 
Pada level budaya dalam pengertian fisiknya, wujud konkrit nilai kreativitas lokal Pamekasan dapat ditemukan dalam beberapa kesenian. Beberapa di antaranya seperti kerapan sapi, tari pecut, sapeh sono', batik sapu jagad. Dari semua wujud kebudayaan tersebut, barangkali kerapan sapi lah yang paling populer di kalangan masyarakat umum. Kerapan sapi sendiri merupakan ajang adu cepat pacuan sapi, sepasang sapi yang di atasnya diberi kayu, berfungsi sebagai tempat joki mengendalikan dan mengontrol laju kecepatan sapi. Kerapan sapi merupakan ajang tahunan yang disebut dengan Gubhengan (Hannan, 2017: 111). Gubhengan sendiri selama ini dikenal sebagai ajang tertinggi lomba pacuan kerapan sapi di Madura. Seringnya even Gubhengan dihadiri oleh peserta kerapan sapi lintas daerah, baik itu dari Sumenep, Sampang, dan Bangkalan.

Selain berupa kesenian daerah, wujud kearifan lokal Pamekasan juga bisa ditemukan pada produk makanan daerah. Salah satu makanan khas daerah yang paling dikenal adalah sate lala' (sate lalat). Terdengar namanya agak aneh karena yang tergambar dalam pikiran adalah jenis hewan berupa lalat. Padahal sesungguhnya tidaklah demikian, sate lala' merupakan sebutan terhadap sate daging pada umumnya, baik sapi, ayam, atau kambing. Hanya, bedanya sate lala' memiliki ukuran lebih kecil ketimbang ukuran sate lainnya. Begitu kecilnya sate ini hingga masyarakat setempat menyebutnya sate lala', yaitu sate dengan cincangan daging sangat kecil seperti lalat. Sate lala' mudah dijumpai di Pamekasan, terutama di sekitaran Jalan Niaga, sentral kuliner Pamekasan. Selain sate lala', juga ada makanan khas lain yang menjadi ciri Pamekasan, seperti halnya petis khas Pamekasan, ba'daba', yaitu cemilan khas Pamekasan yang bahan utamanya terdiri dari ikan lorjuk.

b) Sosial Agama

Sebagai bagian dari daerah Madura, Pamekasan pun memiliki karakter sosial keagamaan yang nyaris hampir ada kesamaan dengan daerah Madura pada umumnya, seperti Bangkalan, Sampang, dan Sumenep. Identitas-identitas berbau keagamaan begitu terasa dan banyak ditemui dalam berbagai aktivitas dan kehidupan sosial masyarakat 
setempat. Kentalnya simbol keagamaan dalam sistem sosial masyarakat tidak lepas dari konteks historis Pamekasan itu sendiri. Karena dalam sejarah perjalanannya, Pamekasan sendiri pernah mengalami kondisi tertentu dimana terdapat beberapa agama yang diketahui pernah menjadi agama mayoritas dan dianuti oleh masyarakat Pamekasan sendiri (Hannan, 2017: 78). Oleh karenanya, wajar bila kemudian banyak ditemui tempat peribadatan dari beragam jenis agama tertentu. Bahkan, sejarah mencatat pada masa pemerintahan Kerajaan Majapahit dulu, agama Hindu menjadi satu-satunya agama mayoritas di Pamekasan, itu terbukti setelah ditemukannya sebuah arkeologi sejarah berupa tempat peribadatan masyarakat Hindu, berupa Vihara di Desa Polagan, Kecamatan Larangan.

Pada level keagamaan daerah, boleh dibilang Pamekasan tercatat sebagai daerah paling heterogen dari keseluruhan daerah Madura lainnya. Ada banyak penganut agama yang tinggal di Pamekasan lengkap dengan tempat peribadatannya. Menariknya, meski realitas keagamaan setempat terbilang heterogen, belum sekalipun muncul konflik di tataran masyarakat yang tumbuh atas dasar sentimen keagamaan. Tempat peribadatan agama-agama dunia, seperti Masjid dan Gereja, baik protestan maupun katolik, lokasinya berdekatan, bahkan saling beriringan. Kenyataan ini mencerminkan betapa tradisi sosial keagamaan masyarakat Pamekasan, sekalipun mereka dikenal memiliki fanatisme keislaman cukup tinggi, mereka juga memiliki sikap penghormatan cukup besar terhadap perbedaan.

Dalam hal pembangunan, Pamekasan mengusung jargon Gerakan Pembangunan Masyarakat Islami, atau populer kita kenal dengan jargon Gerbang Salam. Secara sosiologis, jargon Pamekasan sebagai daerah Gerbang Salam itu ditujukan untuk menselaraskan road map pembangunan dengan realitas tipologi daerah setempat yang selama ini identik dengan keberadaan pesantren. Demikian tergambar jelas dari banyaknya jumlah pesantren yang tersebar luas di Pamekasan, mulai dari 
kecamatan, pedesaan, bahkan hingga perkampungan sekalipun. Berikut peta penyebaran pesantren di Kabupaten Pamekasan.

\section{Tabel I}

Banyaknya Pondok Pesantren dan Santri Menurut Kecamatan di Kabupaten Pamekasan 2015

\begin{tabular}{|c|c|c|c|}
\hline No & Kecamatan & Jumlah Pesantren & Jumlah Santri \\
\hline 1 & Tlanakan & 11 & 2,109 \\
\hline 2 & Pademawu & 5 & 688 \\
\hline 3 & Galis & 2 & 93 \\
\hline 4 & Larangan & 19 & 3,625 \\
\hline 5 & Pamekasan & 11 & 4,394 \\
\hline 6 & Proppo & 10 & 5,54 \\
\hline 7 & Palengaan & 29 & 25,012 \\
\hline 8 & Pegantenan & 24 & 2,422 \\
\hline 9 & Kadur & 20 & 5,585 \\
\hline 10 & Pakong & 11 & 3,481 \\
\hline 11 & Waru & 8 & 2,353 \\
\hline 12 & Batu Marmar & 19 & 3,274 \\
\hline 13 & Pasean & 16 & 1,233 \\
\hline \multicolumn{2}{|c|}{ TOTAL } & 185 & 59,323 \\
\hline
\end{tabular}

Sumber : Kantor Departemen Agama Daerah Kabupaten Pamekasan

Dengan fakta demikian, adalah sangat beralasan jika besarnya jumlah pesantren di Pamekasan dimanfaatkan sebagai strategi pembangunan daerah. Misal, menggalakkan konsep ekonomi lokal melalui kegiatan santripenuership, yakni satu kegiatan perekonomian yang dikemas dalam program pemberdayaan ekonomi komunitas pesantren. Selain berpotensi sebagai penggerak ekonomi, keberadaan pesantren dapat pula dimanfaatkan sebagai pusat pariwisata, misal, menggagas kampung wisata religi yang berbasis pada eksistensi pesantren sebagai ikonnya. Jika gagasan di atas diimbangi oleh strategi marketting yang bagus, dan tata kelola yang baik, bukan tidak mungkin konsep wisata religi berbasis pesantren akan dapat membantu meningkatkan taraf perekonomian daerah.

c) Alam-Lingkungan

Jika aspek budaya dan agama lebih pada nilai lokalitas berupa dimensi sosial, maka aspek alam-lingkungan berisikan nilai lokalitas yang 
bertumpu pada kekayaan alam-lingkungan daerah. Sebagaimana daerah pada umumnya, alam-lingkungan Pamekasan memiliki spot-spot khusus yang menarik dikunjungi. Beberapa nama tempat seperti Pantai Jumiang, Pantai Talang Siring, Taman Brukoh, Bukit Ratu, dan Api Alam tak kunjung padam, kesemuanya adalah tempat-tempat istimewa yang menyimpan eksotisme alam. Api Alam, misal, dikenal sebagai sumber api abadi, lokasinya berada di Desa Larangan Tokol, Kecamatan Tlanakan. Lokasinya yang berada dekat dengan daerah pesisir pantai membuat spot wisata Api Alam menarik dikunjungi. Di sini pengunjung tidak saja dapat menikmati fenomena alam api abadi yang muncul secara alamiah dari dasar perut bumi, namun juga dapat menikmati santapan makanan, seperti ikan bakar dan jagung bakar (Dzulkarnain, 2016: 19).

Selain spot Api Alam, terdapat juga wisata pepantaian seperti Pantai Jumiang dan Pantai Talang Siring. Pantai Jumiang menyimpan eksotisme diri, tidak saja pada hamparan air lautnya yang bening membiru, namun juga ada pada tumpukan bebatuan besar yeng mengeliling sekitar bibir pantai. Pantai ini, selain cocok untuk tempat bersantai menikmati ombak laut sisi timur Pamekasan, pun cocok bagi mereka yang suka memburu sunrise matahari. Melalui pantai ini, kita dapat menyaksikan sunrise yang membentang jelas di ufuk timur pantai Jumiang. Secara geografis, lokasi pantai ini berada di Desa Padellegan, Kecamatan Pademau, Pamekasan (Dzulkarnain, 2016: 21).

Di luar itu semua, kearifan lokal alam lingkungan Pamekasan belakangan juga muncul dari beberapa objek wisata baru, seperti Bukit Brukoh, Bukit Ratu, dan terakhir adalah taman wisata keluarga dan pendidikan Selamat Pagi Madura (SPM). Bukit Ratu adalah Objek Daya Tarik Wisata (ODTW) baru yang dikembangkan oleh masyarakat sadar pariwisata, lokasinya berada di Desa Tebul Barat, Kec. Pagantenan. Keindahan yang ditawarkan Bukit Ratu adalah spotnya yang berada di dataran tinggi Pamekasan bagian utara. Dengan menaiki puncak Bukit Ratu, wisatawan leluasa dapat melihati keindahan Pamekasan dari ketinggian. Menariknya, di lokasi Bukit Ratu wisatawan dapat menikmati 
buah durian segar yang bisa diambil dari pohonnya. Sehingga mereka yang berkunjung di tempat dapat menikmati eksotisme alam sambil lalu berburu buah durian tersebar luas di sekitar Bukit Ratu.

Ekowisata, Kearifan Lokal, dan Pembangunan Pariwisata Daerah Pamekasan Berkelanjutan; sebuah Analisa Teoritik

Salah satu karakteristik pembangunan pariwisata berkelanjutan sebagaimana telah disinggung di atas, itu ada pada kecenderungan memperlakukan prinsip pemerataan dan partisipatif. Pemerataan dan partisipatif, selain mengacu pada perwujudan distribusi kebermanfaatan pembangunan ekonomi secara menyeluruh, juga mengacu pada perwujudan daerah yang mandiri. Memberi keleluasaan bagi setiap daerah untuk dapat mengembangkan pembangunan mereka berdasarkan aspek-aspek keunggulan alam-sosial mereka. Langkah demikian secara langsung akan mendorong setiap daerah menjadi lebih aktif melakukan mengeksplorasi. Menjalankan proses pembangunan ekonomi wilayah masing-masing berdasarkan corak dan khas alam-sosial mereka, tanpa harus menduplikasi, apalagi memaksakan pola pembangunan daerah lain yang sesungguhnya tidak relevan dengan tipologi daerah mereka.

Berkaitan dengan agenda pembangunan pariwisata Pamekasan berkelanjutan, setidaknya ada tiga alasan utama yang mendasari pentingnya penguatan pembangunan Madura yang berkelanjutan melalui gagasan ekowisata berbasis kearifan lokal. Pertama, kenyataan bahwa Pamekasan merupakan bagian daerah kepulauan Madura, itu mengisyaratkan bahwa Pamekasan memiliki tipologi tersendiri yang berlainan dengan daerah di luar Madura. Ada banyak kebudayaan, tradisi, bahasa, dan sekian keanekaragaman lain yang mengidentitas dalam diri masyarakat Pamekasan. Atas dasar kenyataan ini, maka cukup logis kiranya jika semua kekayaan alam sosial tersebut dipelihara dan dilestarikan bersama, dijadikan intrumen pembangunan daerah untuk memaksimalkan pembangunan ekonomi, serta meningkatkan taraf kesejahteraan masyarakat setempat secara menyeluruh. Melalui pemanfaatan dan pemberdayaan masyarakat setempat, praktis dapat 
berdampak signifikan pada tersedianya lowongan pekerjaan, dan partisipasi masyarakat secara menyeluruh. Dalam perspektif pengembangan ekowisata, hal menyangkut pemberdayaan dan partisipasi, itu merupakan terjemahan dari konsep dasar ekowisata, mendatangkan keuntungan bagi masyarakat lokal (Hill Gale, 2009: 81).

Kedua, optimalisasi kebijakan otonomi daerah (otoda). Jika merujuk pada perundangan pembangunan daerah, tujuan perencanaan pembangunan daerah tidak lain adalah mewujudkan pembangunan daerah dalam rangka peningkatan dan pemerataan pendapatan masyarakat, kesempatan kerja, lapangan berusaha, meningkatkan akses dan kualitas pelayanan publik dan daya saing daerah. Pembangunan daerah melalui pendekatan pembangunan berkearifan lokal, selain dapat memperluas ruang gerak daerah dalam mengeksplorasi setiap kekayaan yang ada di masing-masing daerah, pun juga dapat memberi peran signifikan dalam menguatkan sistem otonomi daerah kita. Jika ruang gerak pengelolaan daerah dibatasi, atau lebih-lebih mengalami intervensi, maka yang demikian bukan saja dapat memperlemah sistem otoda, namun juga aktivitas pembangunan wilayah Madura, Pamekasan secara khusus, sebagai sebuah kawasan tritorial yang otonom. Ketiga, nilai lokal sebagai instrumen counter culture (Hannan, 2017: 13). Di tengah massifnya gerak globalisasi yang semakin luas, merupakan suatu yang urgen bagi setiap daerah untuk dapat mempertahankan kebudayaan dan sekian nilai-nilai kreativitas lokal. Dalam konteks inilah, pembangunan pariwisata Pamekasan berkelanjutan melalui konsep ekowisata berbasis kearifan lokal, bisa digunakan sebagai strategi untuk menjaga, melestariskan, dan memberdayakan segala potensi alam-sosial daerah setempat.

Penguatan pembangunan pariwisata Pamekasan melalui pendekatan ekowisata berbasis lokalitas sesungguhnya mengandung relevansi kuat dengan semangat pembangunan berkelanjutan. Apalagi sebagaimana dikemukakan di depan, bahwa salah satu prinsip pembangunan pariwisata berbasis ekowisata adalah pembangunan yang 
berorientasi pada penjagaan, pelestarian, dan pemeliharaan kelestarian lingkungan (Bumi) (Hill Gale, 2009: 79). Pendekatan demikian, selain dapat berfungsi sebagai penguatan sektor ekonomi daerah, pun juga berfungsi besar untuk melestarikan alam lingkungan. Dengan pendekatan kearifan lokal, ada harapan agenda pembangunan di berbagai wilayah Pamekasan dapat terhindar dari segala macam praktik ekploitatif, sehingga tatanan alam-sosial masyarakat Pamekasan akan steril dari praktik-praktik pencemaran lingkungan, polusi udara, dan pengrusakan ekosistem alam.

Dalam perspektif yang lain, pariwisata Pamekasan melalui model ekowisata berbasis kearifan lokal memiliki keunggulan menciptakan sumber perekonomian baru yang mengusung semangat universal. Pemberdayaan terhadap nilai-nilai lokalitas yang ada di Pamekasan praktis akan bersentuhan dengan sistem dan struktur sosial masyarakat, sehingga setiap dari mereka dapat memiliki kesempatan dan peluang cukup terbuka untuk dapat berpartisipasi secara aktif. Prinsip kearifan lokal dalam ekowisata artinya memprioritaskan kehadiran dan keterlibatan masyarakat lokal. Pengelolahan dan pemanfaatan potensi alam diarahkan seluruhnya pada peningkatan mutu hidup masyarakat daerah. Pendekatan ini jelas jauh berbeda dengan konsep industri pariwisata konvensional, yang dalam hubungan kerjanya cenderung eksploitatif dan kapitalis. Dalam konteks pembangunan pariwisata yang berkelanjutan, penguatan nilai kearifan lokal adalah terjemahan dari prinsip kemanusiaan dan kelestarian alam. Bahwa pembangunan berkelanjutan mensyaratkan pada terwujudnya kesejahteraan masyarakat di satu sisi, dan pada sisi bersamaan menjaga keberlangsungan alam lingkungan.

\section{Problem Pembangunan Ekowisata di Pamekasan; antara Tantangan dan Peluang}

Jika menengok bunyi kontitusi kita, implementasi pembangunan pariwisata Pamekasan melalui konsep ekowisata berbasis nilai kearifan lokal sesungguhnya cukup terbuka. Peraturan presiden Nomor 59 tahun 2017 tentang Pelaksanaan Pencapaian Tujuan Pembangunan 
Berkelanjutan menyebutkan, bahwa setiap daerah secara aktif dapat ikut berpartisipasi dalam proses pembangunan daerah masing-masing, baik itu dalam tahap perencanaan, pembangunan, dan evaluasi. Hanya, memang harus diakui sekalipun secara konstitusional sudah mendapat kepastian hukum, namun pada tataran praktiknya masih belum berjalan maksimal, karena masih terkendala oleh beberapa problem. Paling tidak terdapat dua problem krusial yang menjadi penghambat tata kelola ekowisata di Pamekasan saat ini, yaitu problem struktural dan kultural.

Pada aspek struktural, problem penguatan pariwisata berkelanjutan di Pamekasan ditandai oleh belum jelasnya arah pengembangan pariwisata Pamekasan. Ketiadaan tata kelola pengembangan pariwisata yang terarah dan terukur, pada gilirannya membuat potensi pariwisata tidak tertangani secara maksimal. Efek buruk dari ini bukan saja berdampak pada tidak terawatnya lokasi wisata, namun juga pada peluang penguatan ekonomi masyarakat yang ada di sekitarnya, karena pariwisata yang seharusnya berfungsi sebagai roda perekonomian tidak lagi dapat berjalan normal. Selain itu, problem struktural pengelolaan pariwisata di Pamekasan juga muncul akibat rendahnya amenitas dan fasilitas pendukung. Amenitas dapat dimaknai sebagai fasilitas di luar akomodasi yang dapat dimanfaatkan wisatawan selama berada di tempat wisata. Amenitas di sini dapat berupa fasilitas pendukung seperti toko penjual pernak-pernik khas Pamekasan, penyediaan toilet yang bersih, toko cenderamata, dan lain sebagainya. Berkenaan dengan fasilitas, ini sesungguhnya merupakan masalah klasik dalam pengelolaan pariwisata (Dzulkarnain, 2016: 65). Problem fasilitas paling dominan didapati umumnya berupa ketersediaan akses dan transportasi. Kenyataan bahwa akses ke berbagai pariwisata Pamekasan masih relatif kurang baik, misal akses menuju Pantai Jumiang. Di luar itu semua, hal tak kalah krusialnya adalah problem kultural yang berkenaan dengan mentalitas masyarakat. Bahwa belum maksimalnya pengelolaan pariwisata Pamekasan, itu juga terjadi karena rendahnya sumber daya manusia. Rendahnya sumber daya manusia berakibat pada minimnya partisipasi masyarakat, sehingga 
harapan terbentuknya masyarakat sadar wisata itu kemungkinannya sangat kecil.

Hal paling fundamental dalam proses pengembangan dan pembangunan pariwisata Pamekasan berkelanjutan melalui konsep ekowisata berkearifan lokal, sesungguhnya ada pada sejauh mana pembangunan di Pamekasan dapat menjalin sinergitas dengan konstruksi nilai lokal setempat. Setiap pembangunan di Pamekasan harus dapat membangun keselarasan dengan realitas kebudayaan setempat. Karenanya, sinergitas antara masyarakat, organisasi sosial, tokoh masyarakat, dan pemerintah setempat perlu dibangun dan dibentuk sekuat mungkin. Pada batasan ini, pemerintah daerah harus mampu menciptakan terobosan-terobosan baru yang dapat mendukung. Terutama melalui rancangan kebijakan, program, dan agenda kerja yang berkesesuaian dengan aspek sosiologis Pamekasan. Untuk mencapai itu semua, tentu membutuhkan kepaduan para stake holders, serta adanya tata kelola pemerintahan yang baik, transparan, dan akuntabel.

Belajar dari daerah-daerah lainnya, seperti Bali, Yogyakarta, Surakarta, Solo dan semacamnya, kesuksesan mereka membangun industri pariwisata melalui pendekatan lokal tidak lepas dari keberhasilan melakukan branding terhadap segala produk dan nilai lokalitas masingmasing. Untuk itu, selain aspek political will dan sinergitas para pemangku kepentingan, pun juga diperlukan strategi pemasaran daerah yang baik dan efektif. Strategi pemasaran daerah di sini dapat dijalankan dengan memanfaatkan kekuatan teknologi, media massa, dan media sosial. Ada banyak daerah yang berhasil menjalankan agenda pembangunan mereka dengan strategi ini, Banyuwangi, misalnya. Berkenaan dengan pemanfataan teknologi di sini, Richard Florida (1957) menyebutkan, bahwa aktivitas promosi daerah (Pamekasan), kaitannya dengan pembangunan pariwisata Madura berkelanjutan melalui ekowisata berbasis kearifan lokal, hanya akan dapat berhasil manakala memiliki modal tiga (3). Tiga modal tersebut adalah; talenta, teknologi, dan terakhir adalah toleransi (Leksono \& Santosa, 2014: 43). 
Aspek talenta mensyaratkan bahwa sebuah pembangunan ekonomi daerah dapat berjalan berhasil manakala diimbangi oleh ketersediaan aset sumber daya manusia yang tidak saja baik, namun juga kompetitif. Dalam kamus besar bahasa Indonesia. Talenta memiliki kepadanan arti dengan bakat yang berarti dasar kepandaian dan kemampuan diri yang dibawa sejak lahir. Adapun secara terminologi, Lucy (2009) memberi penjelasan bahwa bakat merupakan potensi yang harus distimulasi terlebih dahulu sehingga dapat terlihat sebagai suatu kecakapan, pengetahuan dan kemampuan khusus yang dapat menjadikan individu terampil dan berdaya saing (Lucy, 2009: 48).

Jika dikaitkan dengan studi ini, yakni aspek talenta merujuk pada besarnya perhatian pihak pemerintah daerah Pamekasan terhadap keberadaan sumber daya manusia. Dalam kaitan ini, pemerintah daerah perlu melakukan terobosan bagaimana menstimulus dan mendorong kreativitas masyarakat setempat melalui penguatan pendidikan pariwisata. Mendirikan kelompok Masyarakat Sadar Wisata (POKDOWARIS), kemudian dimbangi oleh kegiatan pelatihan dalam bentuk kegiatan yang bersentuhan langsung dengan aktivitas perniagaan, kerajinan, keterampilan, kesenian. Kegiatan tersebut bisa dalam workshop ekonomi kreatif, seminar, melakukan studi banding, dan lain sebagainya.

Selain aspek talenta, hal lain menurut Florida yang perlu diperhatikan adalah aspek teknologi. Dalam konteks pembangunan ekonomi daerah, aspek teknologi mengisyaratkan bahwa dalam upaya menciptakan pembangunan ekonomi yang berdaya saing dan berkelanjutan, perlu adanya ketersediaan fasilitas penunjang. Terutama penggunaan teknologi kekinian tepat guna yang berorientasi pada kebutuhan dan kepentingan daerah. Berkenaan dengan kajian ini, aspek teknologi merujuk pada ketersediaan dan penggunaan teknologi sebagai medium mempercepat jalannya aktivitas pariwisata di lingkungan daerah Pamekasan. Ketersediaan teknologi tepat guna menjadi niscaya, terutama dalam hal melakukan pemasaran. Belajar dari keberhasilan pembangunan beberapa daerah, seperti halnya Banyuwangi, keberhasilan mereka tidak 
lepas dari peran dan penggunaan teknologi masa kini, khususnya yang berlandaskan pada kecanggihan internet.

Selain talenta dan teknologi, hal yang perlu diperhatikan dalam proses pembangunan pariwisata daerah adalah aspek toleran. Bahwa selain pembangunan fisik melalui ketersediaan sumber daya manusia dan penggunaan daya teknologi tepat guna, pun juga harus diimbangi oleh kesediaan mentalitas diri untuk senantiasa bersikap menghargai dan menerima segala bentuk perbedaan. Kesediaan bersikap toleransi di sini lebih pada tranformasi kultural atau kebudayaan. Merujuk pada teori sibernatika Talcot Parson, bahwa proses pembangunan ekonomi daerah, termasuk di dalamnya pariwisata, itu akan berhasil manakala daerah tersebut telah memiliki sistem kebudayaan yang kuat (J. Goodman \& Ritser, 2010: 211). Sistem kebudayaan yang kuat di sini bukan dalam arti bersikap tertutup pada kebudayaan di luarnya, melainkan lebih pada komitmen diri untuk senantiasa berpegang teguh pada nilai-nilai lokalitas, namun pada saat bersamaan mempunyai sikap keterbukaan pada kebudayaan lain. Konkritnya, sebagai strategi menumbukan sikap toleran di lingkungan Pamekasan, perlu kiranya menggagas pengenalan kebudayaan lintas daerah. Bahkan jika perlu menformulasikannya dalam bentuk even-even khusus, seperti mengadakan Jambore Nasional, Jambore tingkat provinsi, pawai kebudayaan lintas daerah, dan sebagainya. Kegiatan semacam ini, selain berfungsi memberi edukasi kebudayaan pada masyarakat, pun dapat menjadi strategi pemasaran daerah yang berpotensi besar mendatangkan keuntungan ekonomi bagi masyarakat Pamekasan secara khusus.

\section{Simpulan}

Berdasarkan keseluruhan pembacaan di atas, terdapat poin-poin pokok yang menjadi simpulan penulisan paper ini, yaitu:

Pertama, dalam upaya membangun ekonomi daerah Pamekasan yang mengusung visi-misi berkelanjutan, gagasan pembangunan pariwisata berkelanjutan penting dimunculkan. Penguatan ekonomi daerah melalui pendekatan pariwisata berkelanjutan mensyaratkan pada satu 
model pembangunan pariwisata yang tidak saja mengusung visi kemajuan, pertumbuhan, dan pengembangan sektor ekonomi setempat. Lebih dari itu, mengusung semangat pembangunan ekonomi yang partisipatif, universal, emansipatif, dan terpenting dari itu adalah memerhatikan masa depan alam-sosial. Memelihara ekosistem, berorientasi pada pelestarian budaya, dan menjaga keberlangsungan makhluk hidup secara keseluruhan. Hal terpenting di atas segalanya adalah menghadirkan kesejahteraan hidup bagi keseluruhan masyarakat setempat. Untuk bisa mencapai ke sana, maka gagasan pembangunan pariwisata berkelanjutan harus dibangun atas dasar prinsip ekowisata berbasis kearifan lokal.

Kedua, terdapat lima (5) prinsip dasar dalam pembangunan pariwisata berkelanjutan melalui pendekatan ekowisata berkearifan lokal, yaitu; bahwa pariwisata dibangun berdasarkan sumber alamiah dan aspek natural, sisi orisinalitas dan keaslian panorama alam-lingkungan yang ada di Pamekasan; Bersifat berkelanjutan secara ekologis, ekowisata menitikberatkan pada keberlanjutan ekologi alam di Pamekasan; Lingkungannya bersifat edukatif, memberikan pembelajaran dan pengetahuan tentang arti penting menjaga lingkungan alam-sosial sehingga mereka yang bergerak dalam industri wisata, baik sebagai pengelola ataupun pengunjung, semuanya memiliki kesadaran untuk menjaga dan melestarikan alam-sosial di Pamekasan secara bersama dan bertanggung jawab; Menguntungkan masyarakat lokal, yaitu berorientasi pada penguatan daya tawar ekonomi masyarakat Pamekasan, dan secara umum meningkatkan taraf kesejahteraan hidup masyarakat setempat.

Ketiga, untuk bisa sampai ke sana, gagasan tentang strategi pembangunan pariwisata daerah Pamekasan berkelanjutan melalui konsep ekowisata berbasis kearifan lokal, pada tataran teori dan praktiknya harus dilandaskan pada penguatan tiga (3) aspek, yaitu; Talenta, Teknologi, dan Toleransi. Talenta mensyaratkan atas tersedianya sumber daya manusia lokal yang tidak saja terdidik, namun juga terlatih. Sedangkan aspek teknologi mengisyaratkan atas tersedianya teknologi 
yang tidak saja canggih, namun juga tepat guna dan menjalin keselarasan dengan lingkungan alam-sosial. Terakhir adalah toleransi, yakni kesediaan mentalitas diri untuk senantiasa bersikap menghargai dan menerima segala bentuk perbedaan. Kesediaan bersikap toleransi di sini lebih pada tranformasi kultural atau kebudayaan. Mempunyai komitmen diri untuk senantiasa berpegang teguh pada nilai-nilai lokalitas, namun pada saat bersamaan mempunyai sikap keterbukaan pada kebudayaan lain.

\section{Daftar Pustaka}

Butcher, Jim. 2007. Ecotourism, NGO's, and Development: A Critical Analysis. New York: Routledge.

De Jonge, Hubb. 1989. Agama, Kebudayaan, dan Ekonomi: Studi Interdisipliner tentang Masyarakat Madura. Jakarta: Rajawali Press.

Departemen Pendidikan dan Kebudayaan. 1999. Kamus Besar bahasa Indonesia. Balai Pustaka: Jakarta.

Dharmawan, Arya Hadi. "Kearifan Lokal dalam Sistem Sosial Ekonomi Masyarakat Penenun Bugis-Wajo", Jurnal Mudra, Vol. 28, No. 2 (t.b 2013).

Dzulkarnain, Iskandlar. 2016.Sosiologi Pariwisata Madura. Yogyakarta: Pusat Kajian Sosiologi UTM bekerja sama dengan Penerbit Elmater.

Fandeli, Chafid. 2000. Pengusahaan Ekowisata. Fakultas Kehutanan Univ: Gadjah Mada Yogyakarta.

Hannan, Abd. 2017. Fanatisme dan Stigma Sosial Pesantren Miftahul Ulum terhadap Kelompok Muhammadiyah di Pamekasan. Surabaya: Tesis FISIP Universitas Airlangga.

. 2017. Perempuan Madura, Gender, dan Pembangunan. Yogyakarta: Pusat Kajian Sosiologi UTM bekerja sama dengan Penerbit Elmatera.

. "Hegemoni Religio-Kekuasaan dan Transformasi Sosial; Mobilisasi Jaringan Kekuasaan dan Keagamaan Kyai dalam Dinamika Sosio-Kultural Masyarakat Madura," dalam Jurnal Sosial Budaya, Vol. 16, No. 1 ( Juni 2019).

Hill, Jennifer dan Tim Gale. 2009. Ecotourism and Environmental Sustainability: Principles and Practice, Eds. Burlington: Ashgate. 
J. Goodman, Douglass, Ritser, George. 2010. Teori Sosiologi Dari Klasik Sampai Postmodern, Cet. IV, Bantul: Kreasi wacana.

Leksono, Afif dan Purbayu Budi Santosa. "Faktor-Faktor yang Mempengaruhi Pendapatan Industri Kreatif di Indonesia (Tahun 2002 - 2008)." Journal of economic, Vol. 3, No. 1 (t.b 2014).

Lucy, Bunda. 2009. Mendidik Sesuai dengan Minat dan Bakat Anak. Jakarta: Pustaka.

N. Arafah. 2002. "Pengetahuan Lokal Suku Moronene dalam Sistem Pertanian di Sulawesi Tenggara", Tesis Program Pascasarjana Institut Pertanian Bogor.

Nur Hayati, Beti dan Muhammad Arif Fahrudin Alfana. "Kebijakan Kependudukan di Kabupaten Sleman Pasca Berakhirnya MDGS." Natapraja; Jurnal Kajian IImu Administrasi Negara, Vol.4, No. 2 (t.b. 2016).

Penuluh, Sekar dan Meila Riskia Fitri. 2016. Perkembangan Pelaksanaan Sustainable Development Goals (Sdgs) di Indonesia September 2015-September 2016. Paper dalam International NGO Forum On Indonesian Development.

Sanderson, Stephen K. 2011. Makro Sosiologi; sebuah pendekatan terhadap Realitas Sosiologi. Jakarta: Raja Grafindo.

Sulistyo, Budi, dkk. 2010. MDGs Sebentar Lagi. Jakarta: Penerbit Buku Kompas.

Tanaya, Dhayita Rukti dan Iwan Rudiarto. "Potensi Pengembangan Ekowisata Berbasis Masyarakat di Kawasan Rawa Pening, Kabupaten Semarang." Jurnal Teknik PWK, Vol. 3, No. 1 (2014). 
Abd Hannan dan Fithriyah Rahmawati 